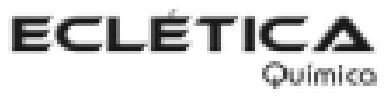

www.scielo.br/eq

Volume 29, número 1, 2004

\title{
Flow injection spectrophotometric determination of adrenaline using a solid-phase reactor containing triiodide ions immobilized in an anion-exchange resin
}

\author{
H. J. Vieira ${ }^{1}$, O. Fatibello-Filho ${ }^{1}$ \\ ${ }^{1}$ Departamento de Química - UFSCar - CEP 13560-970 - São Carlos - SP - Brasil
}

\begin{abstract}
A flow injection spectrophotometric procedure with on-line solid-phase reactor containing ion triiodide immobilized in an anion-exchange resin is proposed for the determination of adrenaline (epinephrine) in pharmaceutical products. Adrenaline is oxidized by triiodide ion immobilized in an anionic-exchange resin yielding adrenochrome which is transported by the carrier solution and detected at a wavelength of $488 \mathrm{~nm}$. Adrenaline was determined in three pharmaceutical products in the $6.4 \times 10^{-}$ ${ }^{6}$ to $3.0 \times 10^{-4} \mathrm{~mol} \mathrm{~L}^{-1}$ concentration range with a detection limit of $4.8 \times 10^{-7} \mathrm{~mol} \mathrm{~L}^{-1}$. The recovery of this analyte in three samples ranged from 96.0 to $105 \%$. The analytical frequency was 80 determinations per hour and the RSDs were less than $1 \%$ for adrenaline concentrations of $6.4 \times 10^{-5}$ and $2.0 \times 10^{-4} \mathrm{~mol} \mathrm{~L}^{-1}$ $(n=10)$. A paired t-test showed that all results obtained for adrenaline in commercial formulations using the proposed flow injection procedure and a spectrophotometric batch procedure agree at the $95 \%$ confidence level.
\end{abstract}

Keywords: adrenaline; flow injection spectrophotometry; solid-phase reactor; pharmaceutical formulations; triiodide ions.

\section{Introduction}

Adrenaline or epinephrine [1-(3,4dihydroxyphenil)-2-methylaminoethanol] belongs to a group of catecholamines, which influences the constriction of blood vessels and control tissue metabolism by increasing the glucose and lactic levels [1]. This drug can be oxidized by various reagents such as iodine [1-4], hypochlorite [5], oxygen [6,7], periodate [8], ammonium metavanadate [9], bromine [10] and lead dioxide [11].

Adrenalinequinone is formed in the first step of adrenaline oxidation followed by cyclization of this quinone to produce leucoadrenochrome. Finally, the leucoadrenochrome is converted into adrenochrome [12].

The drug purity is determined by titration with perchloric acid in glacial acetic acid using crystal violet as indicator [13].

A variety of methods have been used for the determination of adrenaline in pharmaceutical products, including spectrophotometric $[2,4,8,9,14]$, tritimetric $[2,9,10,15]$, fluorimetric $[1,3,16,17]$, and chromatographic $[13,18]$.

Several flow injection procedures have already been used for adrenaline determination using different detectors such as spectrophotometric [7,19-21], chemiluminescent [5,21], spectrofluorimetric [3] and biamperometric [22]. Flow injection-spectrophotometric procedures for adrenaline determination have been also reported employing solid-phase reactors containing microcrystalline manganese dioxide [20], lead(IV) dioxide immobilized in a polyester resin [11] and iodine impregnated in the flexible pump tubing internal wall [3]. However, those flow procedures show limited linear range $[3,11,21]$ and high 
instability of the base line [3] due to the continuous $\mathrm{I}_{2}$ leaching from the flexible pump tubing wall.

In the present work, an analytical procedure using a flow injection analysis with solid-phase reactor to determination of adrenaline in pharmaceutical products was developed. In this procedure, adrenaline was chemically converted into adrenochrome by the triiodide ion $\left(\mathrm{I}_{3}^{-}\right)$

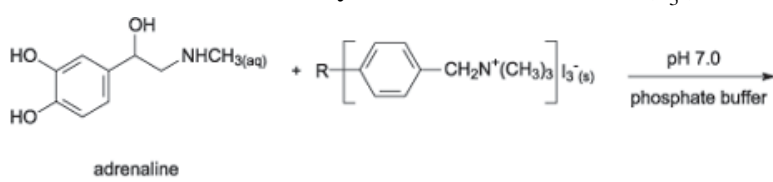

immobilized on the anion-exchange resin R-[-f$\left.\mathrm{CH}_{2} \mathrm{~N}^{+}\left(\mathrm{CH}_{3}\right)_{3}\right] \mathrm{I}_{3}^{-}$, where $\mathrm{f}$ represents a phenyl radi$\mathrm{cal}$ and $\mathrm{R}$ is a styrene-divinylbenzene copolymer (Figure 1). Thus, the adrenochrome was monitorated spectrophotometrically at $488 \mathrm{~nm}$ and the absorbance was related with the adrenaline concentration in the pharmaceutical product solution.

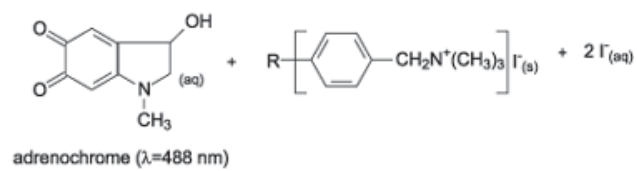

Figure 1. Schematic representation of the reactions at solid-phase reactor (SPR). The redox-pair $\mathrm{I}_{3}^{-} / \mathrm{I}^{-}$is immobilized in the anionexchange resin as R-[-f- $\left.-\mathrm{CH}_{2} \mathrm{~N}^{+}\left(\mathrm{CH}_{3}\right)_{3}\right] \mathrm{I}_{3(\mathrm{~s})}^{-}$and R-[-f- $\left.-\mathrm{CH}_{2} \mathrm{~N}^{+}\left(\mathrm{CH}_{3}\right)_{3}\right] \mathrm{I}_{(\mathrm{s})}^{-}$, respectively. The intermediates adrenalinequinone and leucoadrenochrome are not shown.

\section{Materials and methods}

\section{Chemicals}

A $5.0 \times 10^{-3} \mathrm{~mol} \mathrm{~L}^{-1}$ adrenaline stock solution was prepared by dissolving $48.0 \mathrm{mg}$ of adrenaline (Sigma, St. Louis, USA) in $50 \mathrm{~mL}$ calibrated flask with $5.0 \mathrm{~mL}$ of $0.1 \mathrm{~mol} \mathrm{~L}^{-1} \mathrm{HCl}$ solution and completed with $0.2 \mathrm{~mol} \mathrm{~L}^{-1}$ phosphate buffer solution at $\mathrm{pH}$ 7.0. The reference solutions containing from $6.4 \times 10^{-6}$ to $3.0 \times 10^{-4} \mathrm{~mol} \mathrm{~L}^{-1}$ adrenaline were prepared by dilutions of appropriated volumes of reference stock solution with $0.2 \mathrm{~mol} \mathrm{~L}^{-1}$ phosphate buffer solution (pH 7.0).

All solutions were prepared before the analysis to avoid the adrenaline oxidation by dissolved oxygen.

An anion-exchange resin (Lewatit M500, Bayer) was used to immobilize the triiodide ion $\left(\mathrm{I}_{3}^{-}\right)$.

\section{Apparatus}

In the flow injection system developed, the solutions were pumped with a twelve-channel Ismatec (Zurich, Switzerland) model 7628-50 peristaltic pump supplied with Tygon tubes. A Femto model 435 spectrophotometer (São Paulo, Brazil) equipped with a glass flow-cell (optical path of 1.00 $\mathrm{cm}$ ) was used for the spectrophotometric measurements. Peaks were recorded using a Cole Parmer (Chicago, IL, USA) model 1202-0000 twochannel strip-chart recorder. A laboratory- constructed three-piece manual injector-commutador made of Perspex ${ }^{\mathrm{TM}}$, with two fixed side bars and a sliding central bar was used to introduce sample or reference solutions into the flowing stream. The manifold and reaction coil tubing were constructed with polyethylene tubes $(0.8 \mathrm{~mm}$ i.d. $)$.

The spectrophotometric measurements obtained in static mode were took place with a linear photodiode-array of Hewllet-Packard model $8452 \mathrm{~A}$ with quartz cell (optical path of $1.00 \mathrm{~cm}$ ).

\section{Sample preparation}

Sample aliquots of $0.5 \mathrm{~mL}$ was transferred to a $100 \mathrm{~mL}$ calibrated flask and diluted with phosphate buffer $0.2 \mathrm{~mol} \mathrm{~L}^{-1}(\mathrm{pH} 7.0)$.

Immobilization of triiodide ion $\left(\mathrm{I}_{3}^{-}\right)$in the ionexchange resin

The selected resin exchanger, a copolymer of styrene-divinylbenzene, strongly anion exchanger resin (Lewatit M500, Bayer) with quaternary ammonium functional groups supplied in the chloride form as counter-ions, $\mathrm{R}-\left[-\phi-\mathrm{CH}_{2} \mathrm{~N}^{+}\left(\mathrm{CH}_{3}\right)_{3}\right] \mathrm{Cl}^{-}$, where $\mathrm{R}$ is the styrene-divinylbenzene copolymer, was used for $\mathrm{I}_{3}{ }^{-}$immobilization.

In the immobilization of triiodide ion $\left(\mathrm{I}_{3}^{-}\right)$, the resin conversion was carried out in a glass column, as described previously [23] and shown in Figure 2. 


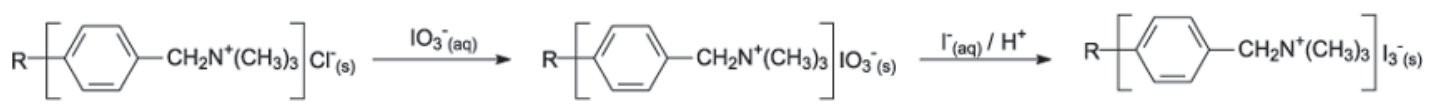

Figure 2. Schematic representation of reactions at resin to immobilization of triiodide ions $\left(\mathrm{I}_{3}^{-}\right)$in the exchange-anionic resin.

Flow diagram

A schematic diagram of the flow injection system used for adrenaline determination is shown in Figure 3. The solid-phase reactor (SPR) was inserted between injector and spectrophotometric detector. The adrenaline or reference solutions were injected into the carrier $0.2 \mathrm{~mol} \mathrm{~L}^{-1}$ phosphate buffer solution at $\mathrm{pH} 7.0$ with the aid of an injectorcommutador (IC) with a loop volume of $250 \mathrm{~mL}$. A solution of $0.2 \mathrm{~mol} \mathrm{~L}^{-1}$ phosphate buffer $(\mathrm{pH} 7.0)$ flowing at $2.1 \mathrm{~mL} \mathrm{~min}^{-1}$ was used as carrier. Thus, the adrenochrome produced into SPR was monitored at $488 \mathrm{~nm}$ (D) and the absorbance was recorded.

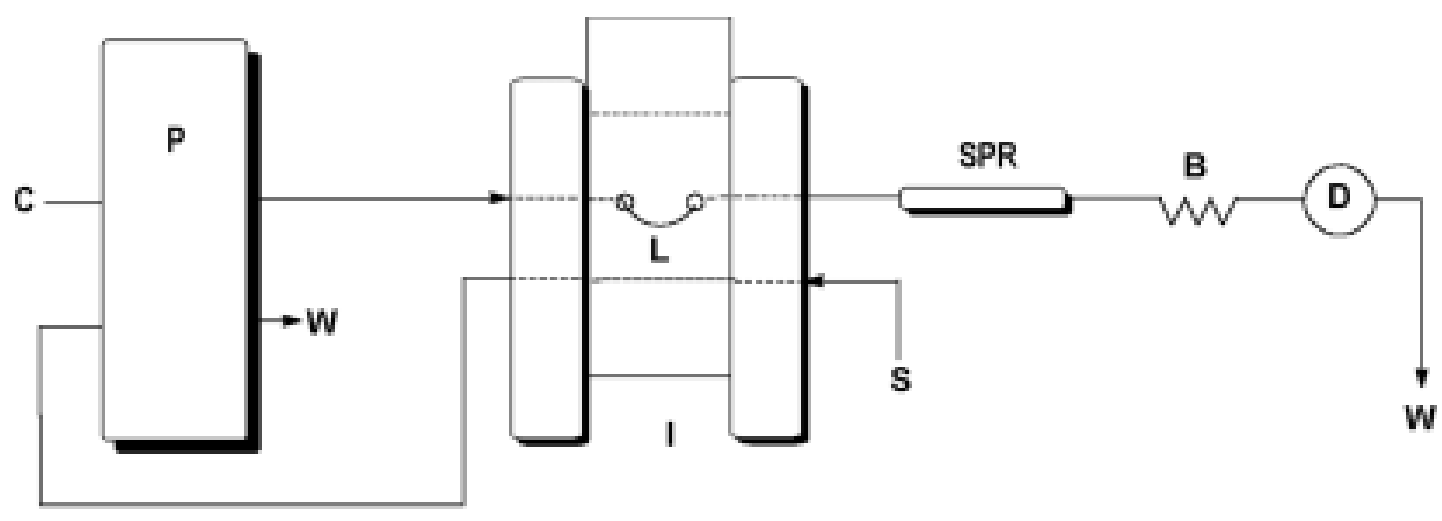

Figure 3. Flow injection assembly for adrenaline determination. C: carrier stream (phosphate buffer $0.2 \mathrm{~mol} \mathrm{~L}^{-1}, \mathrm{pH} 7.0,2.0 \mathrm{~mL}$ $\left.\mathrm{min}^{-1}\right)$, S: sample or reference solutions volume $(250 \mathrm{~mL}, 50 \mathrm{~cm})$, SPR: solid-phase reactor $(10 \mathrm{~cm} \mathrm{x} 1.2 \mathrm{~mm}$ i.d.), B: coil $(30 \mathrm{~cm})$, D: spectrophotometric detector (488 nm), P: peristaltic pump, I: injector-commutator, W: waste.

\section{Results and discussion}

Several parameters had to be optimized in order to achieve the optimal conditions to promote the oxidation of adrenaline at SPR and spectrophotometric detection of adrenochrome produced.

\section{Selection of carrier solution}

As the reaction between adrenaline and triiodide ion depends strongly on the acidity of the carrier stream, water, hydrochloric acid, acetate buffer, borate buffer and phosphate buffer solutions were tested injecting $6.1 \times 10^{-4} \mathrm{~mol} \mathrm{~L}^{-1}$ adrenaline solution. The best results (higher ratio of signal to noise and better base-line stability) were obtained using a $0.2 \mathrm{~mol} \mathrm{~L}^{-1}$ phosphate buffer solution at $\mathrm{pH}$ 7.0 as carrier. Therefore, this buffer solutions was selected in further investigations.

\section{Solid-phase reactor optimization}

The reactor containing ion exchange resin with triiodide ion immobilized was constructed using glass tubes with $1.2 \mathrm{~cm}$ of internal diameter. 
The effect of reactor length of 5.0, 10 and $15 \mathrm{~cm}$ on the analytical response was studied. It was found that the highest analytical signal was obtained when a $10-\mathrm{cm}$ reactor length was employed. The 5-cm reactor length gave a lower response owing to the short residence time. On the other hand, the $15-\mathrm{cm}$ reactor length the absorbance signals was lower than those obtained with $10-\mathrm{cm}$ reactor length probably due to higher dispersion of sample zone.

\section{Optimization of FIA parameters}

The effect of the FIA parameters on the analytical response (absorbance) were studied by changing each variable while keeping all others unchanged.

The effect of injected volumes from 62.5 to $500 \mathrm{~mL}$ (L varying from 12.5 to $100 \mathrm{~cm}$ ) on the analytical signal for $5.0 \times 10^{-4}$ mol L-1 adrenaline solution was initially evaluated. The increase of the sample volume resulted in an increase of absorbance. A $250 \mathrm{~mL}(\mathbf{L}, 50 \mathrm{~cm})$ volume of sample or reference solution was selected because it resulted in higher sensitivity and reasonable analytical frequency.

The effect of coil B length was investigated in the range from 30 to $320 \mathrm{~cm}$, for $5.0 \times 10^{-4} \mathrm{~mol} \mathrm{~L}^{-1}$ adrenaline solution. The coil B is used to transport the adrenochrome formed in the reactor (SPR) to the spectrophotometric detector (D). The peak heights strongly decrease with the increases of the coil length up to $320 \mathrm{~cm}$. A $30 \mathrm{~cm}$ coil B length was chosen, taking into account sensitivity of the procedure.

The effect of the flow rate of carrier stream $\left(0.2 \mathrm{~mol} \mathrm{~L}^{-1}\right.$ phosphate buffer at $\left.\mathrm{pH} 7.0\right)$ from 0.6 to $2.6 \mathrm{~mL} \mathrm{~min} \mathrm{~m}^{-1}$ on the absorbance signal was investigated inserting $250 \mathrm{~mL}$ of 5.0 $\mathrm{x} 10^{-4} \mathrm{~mol} \mathrm{~L}^{-1}$ adrenaline solution. The flow rate

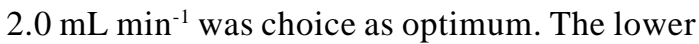
flow rate of carrier stream was found to give lower absorbance signals probably due to higher dispersion of the sample zone. When a higher flow rate of carrier stream was employed, the absorbance signal decreased probably due to shorter residence time. Additionally, an excessive hydrodynamic pressure occurred.

\section{Recovery, repeatability and lifetime of SPR}

Recoveries from 96.0 to $105 \%$ of adrenaline were obtained from commercial formulations $(n=3)$ using the proposed flow injection procedure under optimized conditions, as shown in the legend of Figure 3. In this study, $13.7,27.5$ and $38.5 \mathrm{mg} \mathrm{L}^{-1}$ of adrenaline were added separately to each sample. Table 1 presents the results obtained in the additionrecovery experiments. The recovery results obtained suggested an absence of matrix effect on those determinations and the accuracy of the proposed procedure.

The relative standard deviations (RSDs) were lower than $1 \%$ for adrenaline concentrations of $6.4 \times 10^{-5}$ and $2.0 \times 10^{-4} \mathrm{~mol}$ $\mathrm{L}^{-1}(\mathrm{n}=10)$.

The lifetime of solid phase reactor SPR containing triiodide ions immobilized was evaluated observing the slope of analytical curve by one month, using the same SPR. In this period, was injected more than 600 reference solutions without lose of sensibility.

\section{Analytical curve and application}

The proposed flow injection system was applied to determine adrenaline in commercial pharmaceutical formulations. The results of the analysis of adrenaline are presented in Table 2. The obtained results were compared with those obtained with the recommended USP method [13] at the $95 \%$ confidence level when applying a paired $t$-test. The analytical curve was found to be linear in the range from $6.4 \times 10^{-6}$ to $3.0 \mathrm{x}$ $10^{-4} \mathrm{~mol} \mathrm{~L}^{-1}$ and is described by the equation $\mathrm{A}$ $=0.015+2809.4 \times \mathrm{C} ; \mathrm{r}=0.9998$, where $\mathrm{A}$ is the absorbance measured and $\mathrm{C}$ is the adrenaline concentration in mol $\mathrm{L}^{-1}$, with a detection limit of $4.8 \times 10^{-7} \mathrm{~mol} \mathrm{~L}^{-1}$ (three times the blank standard deviation/slope) and analytical frequency of 80 determinations per hour. 
Table 1. Results of recovery studies using pharmaceutical preparation spiked with three different reference concentrations of adrenaline.

\begin{tabular}{lccc}
\hline \multirow{2}{*}{ Sample } & \multicolumn{2}{c}{ Adrenaline $\left(\mathrm{mg} \mathrm{L}^{-1}\right)^{\mathrm{a}}$} & \multirow{2}{*}{ Recovery (\%) } \\
\cline { 2 - 3 } & Added & Found & 104 \\
\hline 1 & 13.7 & $14.3 \pm 0.1$ & 100 \\
& 27.5 & $27.5 \pm 0.1$ & 99.5 \\
& 38.5 & $38.3 \pm 0.2$ & 105 \\
& 13.7 & $14.4 \pm 0.1$ & 100 \\
& 27.5 & $27.6 \pm 0.1$ & 96.0 \\
& 38.5 & $37.7 \pm 0.2$ & 99.3 \\
& 13.7 & $13.6 \pm 0.1$ & 99.3 \\
& 27.5 & $27.3 \pm 0.2$ & 101 \\
\hline
\end{tabular}

${ }^{a} \mathrm{n}=3$.

Table 2. Determination of adrenaline in pharmaceutical products using the proposed flow injection and spectrophotometric USP [13] procedure.

\begin{tabular}{cccccc}
\hline \multirow{2}{*}{ Sample } & Label & \multicolumn{2}{c}{ Adrenaline $\left(\mathrm{mg} \mathrm{L}^{-1}\right)^{\mathrm{a}}$} & \multicolumn{2}{c}{ Relative error (\%) } \\
\cline { 3 - 6 } & value & $\begin{array}{c}\text { Spectrophotometric } \\
\text { USP }\end{array}$ & Flow injection & $\mathrm{Re}_{1}{ }^{\mathrm{b}}$ & $\mathrm{Re}_{2}{ }^{\mathrm{c}}$ \\
& & $1.68 \pm 0.01$ & $1.81 \pm 0.05$ & -0.6 & 7.7 \\
\hline 1 & 1.82 & $1.82 \pm 0.01$ & $1.81 \pm 0.01$ & -0.6 & -0.5 \\
2 & 1.82 & $1.75 \pm 0.01$ & $1.77 \pm 0.02$ & -2.7 & 1.1 \\
\hline
\end{tabular}

${ }^{a} \mathrm{n}=3$, confidence level $95 \%$.

${ }^{\mathrm{b}} \mathrm{Re}_{1}$, FIA $v s$ label value.

${ }^{\mathrm{c}} \mathrm{Re}_{2}$, FIA $v$ s spectrophotometry value.

\section{Conclusions}

The spectrophotometric flow injection system with on-line packed reactor containing triiodide ions immobilized on an anionicexchanger resin as oxidant agent is precise, accurate and sensitive to determining adrenaline in pharmaceutical formulations.

\section{Acknowledgements}

Financial supports from FAPESP and CNPq are gratefully acknowledged.

Recebido em: 10/02/04

Aceito em: 23/03/04 
H. J. Vieira; O. Fatibello-Filho. Sistema de análise por injeção em fluxo para determinação de adrenalina usando reator de fase sólida contendo íons triiodeto imobilizado em resina aniônica.

Resumo: Um sistema de análise por injeção em fluxo de linha única com um reator em fase sólida contendo triiodeto $\left(\mathrm{I}_{-}{ }_{3}^{-}\right)$imobilizado acoplado entre o injetor e o detector foi utilizado para determinação de adrenalina em ampolas. Nesse sistema, a adrenalina foi oxidada pelo ânion triiodeto imobilizado na resina a adrenocromo, sendo esse produto monitorado espectrofotometricamente em $488 \mathrm{~nm}$. A curva analítica foi linear no intervalo de concentração de adrenalina de $6,4 \times 10^{-6}$ a $3,0 \times 10^{-4} \mathrm{~mol} \mathrm{~L}^{-1} \mathrm{com}$ um limite de detecção de $4,8 \times 10^{-7} \mathrm{~mol} \mathrm{~L}^{-1}$ (três vezes o desvio padrão do branco/inclinação da curva analítica). A frequiência analítica foi de 80 determinações por hora, a recuperação variou de 96,0 a $105 \%$ e os desvios padrão relativos foram menores que $1 \%$ para soluções de adrenalina de $6,4 \times 10^{-5} \mathrm{e} 2,0 \times 10^{-4}$ $(\mathrm{n}=10)$. Aplicando-se o teste- $t$ aos resultados obtidos empregando-se o procedimento proposto e aqueles empregando-se um procedimento espectrofotométrico houve uma concordância dos resultados a um nível de confiança de $95 \%$.

Palavras-chave: adrenalina; análise por injeção em fluxo; reator em fase sólida; formulações farmacêuticas; íons triiodeto.

\section{References}

[1] D. Glic, Methods of Biochemical Analysis, Interscience, New York, 1957, p. 57-82.

[2] F. B. Salem, Anal. Lett. 26 (1993) 1959.

[3] A. Kojlo, J. Martínez-Calatayud, Anal. Chim. Acta 308 (1995) 334

[4] M. J. Rodríguez-Dopazo, M. Silva, D. Pérez-Bendito, Microchem. J. 39 (1989) 235.

[5] C. Zhang, J. Huang, Z. Zhang, M. Aizawa, Anal. Chim. Acta 374 (1998) 105.

[6] S. G. Palop, A. M. Romero, J. Martínez-Calatayud, J. Pharm. Biomed. Anal. 27 (2002) 1017.

[7] J. J. Berzas Nevado, J. M. L. Gallego, P. Buitrago Laguna, J. Pharm. Biom. Anal. 14 (1996) 571.

[8] M. E. El-Kommos, F. A. Mohamed, A. S. Khedr, Talanta 37 (1990) 625.

[9] F. B. Salem, Talanta 34 (1987) 810

[10] D. Amin, Analyst 111 (1986) 255.

[11] M. F. S. Teixeira, L. H. Marcolino-Junior, O. FatibelloFilho, Il Farmaco 57 (2002) 215.

[12] S. H. Kim, J. W. Lee, I-H. YEO, Electrochim. Acta 49
(2000) 2889.

[13] United States Pharmacopeia National Formulary XXXIII, US Pharmacopeial Convention, Rockville, 1985, p. 375.

[14] M. L. Iskander, H. A. A. Medien, Microchem. J. 41 (1990) 172.

[15] M. M. Tuckerman, Pharm. Sci. 51(1962) 700.

[16] S. Honda, T. Acaki, M. Takahashi, K. Kakehi, Anal. Chim. Acta 149 (1983) 297.

[17] H. Nohta, A. Mitsui, Y. Ohkura, Anal. Chim. Acta 165 (1984) 171.

[18] M. Marazuela, L. Agüí, A. González-Cortéz, P. YáñezSedeño, J. M. Pingarón, Electroanalysis 11 (1998) 1333.

[19] M. Carmona, M. Silva, D. Pérez-Bendito, Analyst 116 (1991) 1075.

[20] A. Kojlo, J. Martínez-Calatayud, Anal. Lett. 28 (1995) 239.

[21] N. T. Deftereos, A. C. Calokerinos, C. E. Efstathiou, Analyst 118 (1993) 627.

[22] J. V. G. Mateo, A. Kojlo, J. Pharm. Biomed. Anal. 15 (1997) 1821.

[23] K. O. Lupetti, I. C. Vieira, H. J. Vieira, O. Fatibello-Filho, Analyst, 127 (2002) 525. 